\title{
ОСОБЛИВОСТІ ФУНКЦІОНУВАННЯ СИСТЕМИ АДМІНІСТРУВАННЯ ЗЕМЕЛЬНИХ РЕСУРСІВ МІСТА
}

\author{
H.M. Музика \\ кандидат економі чних наук \\ Національний університет «Львівська політехніка» \\ (Україна, м. Львів; e-mail: Myzuka69@ukr.net) \\ М.C. Маланчук \\ кандидат технічних наук, доцент \\ Національний університет "Львівська політехніка" \\ (Україна, м. Львів; e-mail: malanchuk.mari@gmail.com)
}

\begin{abstract}
У земельному фооні України найбілъи багатогалузевими і складними є землі міст, особливо великих, які одночасно є $і$ місием постійного проживання населення, $i$ об' єктом розмішення основної маси капіталовкладенъ. Питаннями регулювання земельних відносин, організацією і управлінням шуодо використання земель міста як иілісного комплексу займається адміністрування. Важливим $\epsilon$ бормування механізму адміністрування земельних ресурсів (АЗР), яке повинно перебрати на себе управлінсъкі бункиї як принциипу. 3 розвитком ринку дедалі більшої популярності набирає інститут власності, зокрема $і$ земельної. Постійний проиес реббормування земельних відносин потребує вирішення питанъ щодо адміністративного управління земляли. Наразі актуальними є всі питання шодо земель сільсъкогосподарсъкого призначення, які формуватимуть ринок земель $i$ відносин у иій системі, а також щодо органів, які маютъ здійснювати управлінсъку фбункиію тошо. Розвиток народного господарства у місті обумовлює постійну потребу в землі як просторового базису об'єктів як житлового, так і промислового призначення. Пошук таких резервних територій у містах здійснюєтъся з метою відводу земель для ицих потреб, щуо надзвичайно актуально, оскільки земельні угіддя є просторово обмеженими. На місиеві органи влади покладаєтъся відповідальність за розвиток міста, зокрема бормування земельних відносин. Для вирішення изих питанъ пропонується концепція розвитку адміністрування земельних ресурсів через запровадження та подальше вирішення основних стратегічних завдань (видів робіт) у містах.
\end{abstract}

Ключові слова: адміністрування земельних ресурсів, земельна ділянка, місто, інвестиції.

Постановка проблеми. Удосконалення системи використання земель міста через виконання встановлених видів робіт.

Аналіз останніх досліджень і публікацій. Адміністрування земельних ресурсів — відносно нове трактування у науково-практичному застосуванні в Україні, проте серед провідних науковців[1-4] займає чільне місце у галузі дослідження щодо забезпечення сталого розвитку.

Проблематику адміністрування земельних ресурсів досліджували вітчизняні вчені Л. Перович, I. Перович [5]. Спільні проблеми у своїх дослідженнях розв'язують Д. Добряк, А. Третяк [6], Р. Курильців [7], О. Дорош, Н. Третяк, А. Сохнич, О. Муляр, П. Кулинич, Д. Егіашвілі, які провели удосконалення модуля адміністрування земельних ресурсів в Україні [8].

Виділення невирішених раніше частин загальної проблеми. Законодавство України щодо рефрормування земельних ресурсів є недостатньо орієнтованим на вирішення всіх питань щодо користування землями у містах в умовах приватизації. Також неврегульованість правового забезпечення АЗР у містах, постійні зміни у містобудівній документації у правилах її використання призводить до довготривалих спорів у часі між суб'єктами господарювання на території міста. Потребує вдосконалення і економічний механізм впливу на використання міських земель, удосконалення нормативно-організаційних методів регулювання землекористування у місті. Функціонування системи адміністрування земельних ресурсів міст фрункціонуватиме через послідовне виконання встановлених видів робіт.

Метою дослідження є розробка та наукове обгрунтування виконання встановлених видів робіт, які забезпечать повноцінне функціонування системи адміністрування земельних ресурсів на противагу управлінню земельних ресурсів. 
Матеріали та методи. Для розкриття тематики використовували організаційні, технологічні, адміністративні, економічні методи досліджень, що застосовуються на практиці і забезпечують повноцінне фрункціонування АЗР.

Теоретичну та методологічну основу дослідження становить діалектичний метод пізнання процесів цілеспрямованого впливу на організацію АЗР в умовах рефрормування земельних відносин у міському господарстві.

Питання АЗР міста доцільно дослідити абстрактно-логічним методом, основою якого $є$ : окремо взяте явище - складова частина аналіз і продовжується можливим їх узагальненням - синтезом.

Викладення основного матеріалу. Важливим напрямом подальшого розвитку систем використання земель та управління в Україні є фрормування земельного адміністрування (land administration), що існує у країнах Європи. До того ж Євроінтеграція України потребує впровадження європейських стандартів щодо управління земельних ресурсів. Зважаючи на світовий досвід, запровадження системи АЗР в Україні сприятиме розв' язанню проблем у подальшому вдосконаленні земельних відносин, ефрективному використанні землі та її ринку.

Для повноцінного фрунціонування системи адміністрування земельних ресурсів міста доцільно забезпечити виконання відповідних робіт та постійного іх удосконалення, як-от:

- створення концепції розвитку міста;

- забезпечення інвестиційної привабливості;

- проведення інженерної підготовки та облаштування території — елементи адміністрування земельних ресурсів міста; міста;

- фрункціональне зонування території

- фрормування системи платежів міста;

- виготовлення плану земельно-господарського впорядкування - основа рефрормування відносин власності в місті;

- створення напрямів удосконалення механізму соціально-економічних відносин міста і приміської зони.

Розглянемо докладніше кожен із запропонованих пунктів.

Кониелиія розвитку міста.

Усі зміни, що відбуваються у місті, реалізовуються у сорері землекористування. Землі, як об'єкт відносин, є операційним просторовим базисом соціально-економічного та містобудівного розвитку, що поєднує сталу муніципальну інфраструктуру і юридичну складову міста, як земельно-господарську систему.

У межах міської межі, згідно з переважним типом землі за фрункціональним викорис- танням виділяють райони, розділені між собою магістралями загальноміського та районного рівнів, смугами відводу залізниці, природними межами (ріки, струмки, канали, рівчаки тощо), а також - межами ділянок об'єктів підприємств, що забезпечують раціональне використання та охорону міських земель.

Землі міст — це земельні ресурси України, що відносяться до категорії земель населених пунктів і налічують всі території в межах міст, незалежно від цільового використання [9].

Територію міста необхідно розглядати як складну земельно-господарську систему, що формується за адміністративно-територіальною ознакою і потребує подальшої структуризації за правовим і господарським станом.

Інвестииійна привабливістъ.

Розвиток економіки держави залежить від впровадження рефрорм, головними з яких є соціально-економічні. Успішне звершення цих рефрорм буде обумовлено змістом, правами і обов'язками органів місцевого самоврядуванням як інституції, права якої зафіксовано у Конституції України, створенням надійної економічної бази та в досконалих механізмів їі фрункціонування.

Нині найактуальнішим залишається розроблення і впровадження дієвих засобів щодо управління використанням і забудовою території міст. Це сприятиме наповненню міського бюджету, інвестиційним надходженням, покращенню економічного клімату і, як наслідок, розвитку міста.

Управлінські рішення будуть дієвими, якщо грунтуватимуться на демократичності у напрямі проведення рефрорми загалом, а не окремої галузі.

Для створення інвестиційного клімату, що забезпечить всебічний розвиток міста, необхідно вжити низку заходів, зокрема:

- пріоритетним завданням органів місцевої влади є покращення розвитку усіх сорер міста через максимальне залучення вітчизняних та іноземних інвестицій у сферу: торгового, готельного, транспортного, офісного будівництва, благоустрою території, рекреаційної діяльності, реконструкції неефективних об'єктів тощо; через можливість цільового надання земельних ділянок у довгострокове користування інвестору з правом продовження термінів або викупу їх за дотримання чинного законодавства;

- сприяти інвесторам у виборі земельних ділянок, що перебувають у державній і комунальної власності, для здійснення підприємницької діяльності на перспективу;

- надання інвесторам земельних ділянок для будівництва комплексів різного призначення, складських приміщень, транспортних 
засобів, постачальницької мережі з розташуванням у районах залізниці і автомагістралі та дотриманням визначених захисних зон.

- упорядкування існуючої торговельної мережі з ліквідацією стихійних ринків продовольчих та непродовольчих товарів.

Для цього під час розробки проектів розвитку міста необхідно значну увагу приділити розділу інвестиційної привабливості, за допомогою якого можна інформувати інвесторів і зацікавити їх у фрінансуванні проектних рішень.

За результатами дослідження українського представництва міжнародної антикорупційної мережі Transparency International було визначено рівень інвестиційної прозорості [11]. Рейтинг міст України за прозорістю інвестиційного сектора наведено на рис. 1.

Формуючи рейтинг, особливу увагу звертали на антикорупційні програми, на існування важелів та можливостей у інвестиційному секторі, публічність інформації щодо конфлікту інтересів у міських радах, стан та діяльність підприємств міста.

Шкала оцінки фрормувалася за відповідною бальністю (5-6, 6-7, 7-8, 8-9, 9-10, 10-15, 15-20). 3 наведеної бальної статистики щодо рейтингу прозорості інвестиційного сектора перше місце посідає м. Івано-Франківськ (15,0 балів); на другому — м. Київ $(12,7)$; на третьому — м. Вінниця $(12,0)$; на четвертому м. Львів (10,75 балів).

Отже, інвестиційний процес залежить від прозорості АЗР, політики органів міської влади та стабільного законодавства.
Інженерна підготовка та облаштування території - важливі елементи адміністрування земельних ресурсів міста.

Ринкова економіка, різноманіття фрорм власності на землю та її використання підвищує значення містобудівної документації, яка $\epsilon$ важливою ланкою реформування земельних відносин у місті, а також погодження приватних і громадських інтересів.

Під час формування міської території із багатьох ділянок, і особливо забудованих, виникають різні проблеми, розв'язувати які повинен відповідний підрозділ у структурі містобудівної діяльності, продуктом якої і є містобудівна документація. Містобудівна документація виготовляється з метою законодавчо обгрунтованого використання і забудови території міста.

Дотримання раціональної планувальної організації території міста та погодження взаємного розміщення виробничих комплексів, житлових районів, громадських центрів, зон масового відпочинку та інших об'єктів має забезпечувати містобудівне регулювання земельних відносин.

Важливим у містобудуванні є діяльність, призначена для організації матеріально-просторового середовища, що повинно відбуватися комплексно.

Для розширення території міста, як показує практика, залучаються прилеглі території сіл, у т.ч. і сільськогосподарські угіддя. Такі рішення є не завжди економічно обгрунтованими, а інтереси місцевого населення майже зовсім не враховуються. У такому рішенні $є$

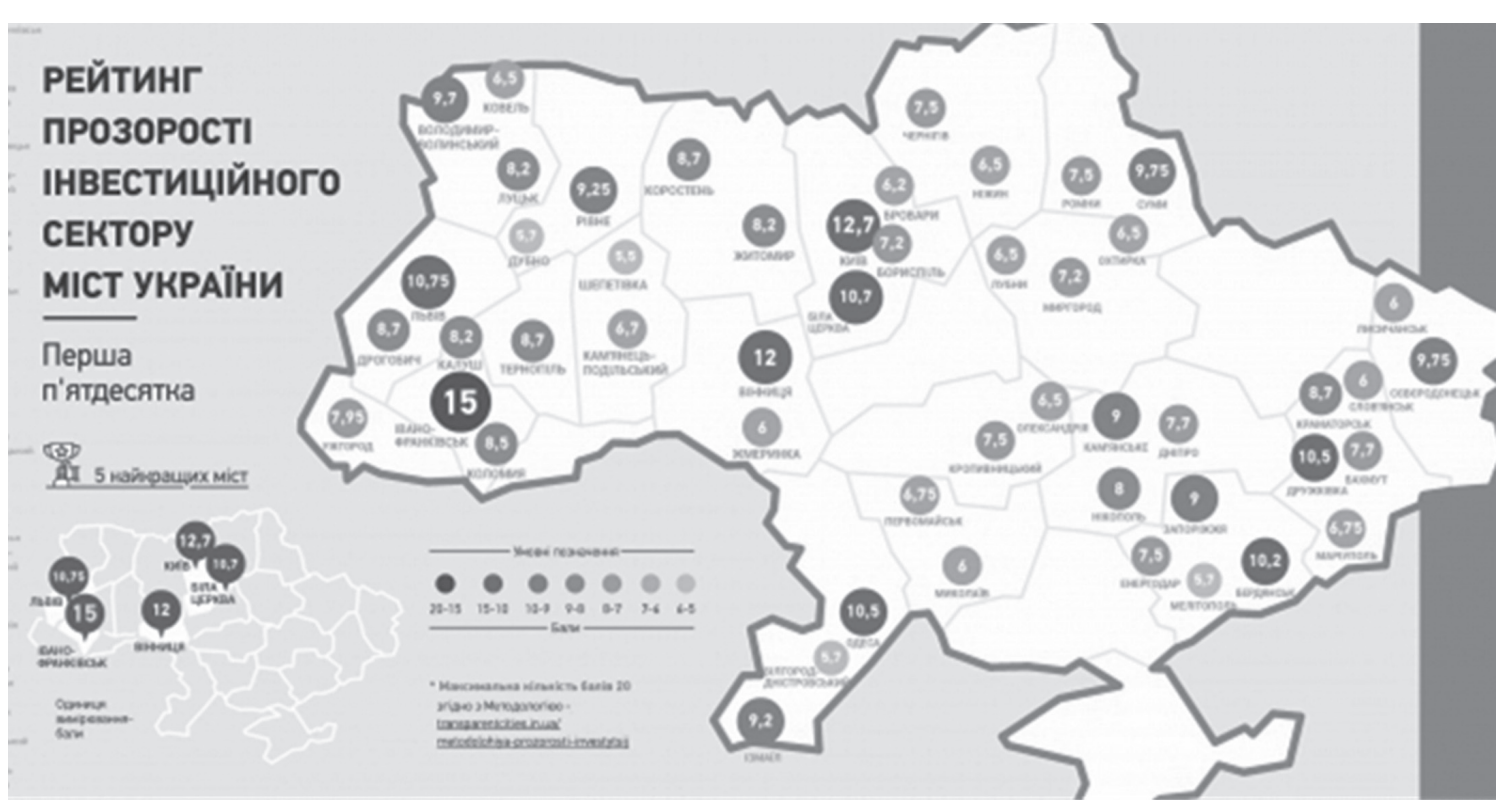

Рис. 1. Рейтинг прозорості інвестииійного сектора міст України 
деяка практичність, а саме, беруться до уваги основі затрати на будівництво об'єктів і благоустрою території як економічні показники. Тому проводячи оцінку забудови, вигідно використовувати ріллю приміських зон (сіл), а не території, зайняті старими і малоцінними будівлями, а також території, що потребують докорінної підготовки для використання у містобудуванні.

Досвід економічно розвинених країн засвідчує, що ринкова економіка передбачає ширшого використання у господарській діяльності міста та містобудівному процесі порушених і обмежено придатних земель із застосуванням економічних стимулів.

Зважаючи на це, першочергового значення для містобудівних потреб набувають інженерно-технічні характеристики земель, що враховуються під час будівництва, як-от: грунти, нахил місцевості, глибина залягання підгрунтових вод, наявність інженерних мереж, стан існуючих будівель, просторове розташування земельної ділянки тощо. Узагальнення цих характеристик надає змогу групувати ділянки за придатністю, а саме: придатні, малопридатні та непридатні для будівництва i ï перспективного використання.

Важливим є проведення органами влади міста політики збільшення оцінки земель державної, комунальної та приватної власності шляхом розвитку інженерної інфраструктури, благоустрою, інженерної підготовки території, проведення інженерно-технічних заходів з будівництва захисних споруд, вертикального планування, інженерних облаштувань території тощо. Саме проведення благоустрою та інженерного облаштування території істотно впливає на вартість земельної ділянки у містах, а отже і на рівень дохідності бюджету міста. мicma.

Функиіональне зонування територіі

Міські землі за фрункціональним призначенням є важливою характеристикою території із визначеними параметрами, елементами середовища та порядком їх розміщення в просторі.

Для кожної функціональної зони укладається перелік можливого використання об'єктів, що існують на будь-якій ділянці в зоні і відповідають її «цільовому призначенню». Проте функціональна зона визначається як окрема група ділянок за їх використанням, які власник або користувач може обирати самостійно у будь-який час. Крім того, залученню інвестицій щодо використання землі сприятиме, зокрема:

- якщо власник або користувач вважатиме певне використання прибутковим та до- цільним для цієї землі, то він має змогу змінити існуюче використання на інше;

- якщо перший вид використання застарів або є неконкурентним на ринку.

Збільшення інвестицій, розширення свободи вибору у використанні земель та можливості коригування їх цільового призначення залежить від розвитку ринку на певний момент часу і сприяє розширенню видів експлуатації території, що забезпечує власнику або користувачу земельної ділянки вигідні умови iї використання. Проте вимоги, що існують для забезпечення функціональної, екологічної, архітектурно-планувальної та іншої єдності різних видів використання, обмежує ці можливості.

Формування системи платежів міста.

Платне використання землі - це один із важелів, що закріплений законодавством України. Орендна плата, земельний податок є обов'язковими для всіх власників і користувачів земельних ділянок. Через купівлю-продаж та проведення аукціонів з нерухомості, прав на неї фрормується власність на землі та об'єкти нерухомості.

План земельно-господарсъкого впорядкування - основа ребормування відносин власності в мicmi.

Використання земель міста відбувається згідно з проектами планування та забудови міста і планів земельно-господарського впорядкування (ПЗ-ГВ) [11]. На сьогодні проекти планування та забудови міст розробляються за правилами, встановленими у період існування лише державної власності на землю, де землекористування було безкоштовним.

Власники землі та користувачі, інвестори хочуть здійснювати свої наміри щодо житлового, виробничого, культурно-побутового або іншого будівництва 3 дотриманням обмежень і умов, визначених чинним законодавством. Слід зауважити, що генплан міста відповідно до свого призначення не може виступати основним документом, що регулює процес використання земель.

Зважаючи на те, що між документацією генплану і АЗР існують протиріччя у правовому полі, інвестор або власник землі не забезпечується необхідною інформацією для правового вирішення питань щодо вкладення коштів у землю, а це своєю чергою призупиняє економічний розвиток певної території і міста загалом. Так, принципи управління використанням i забудовою населених пунктів залишилися 3 дорефрорменого періоду і нині не відповідають вимогам часу. 3 огляду на це, виникла необхідність змін із застосування демократичних та ринкових механізмів фрормування та прийняття 
рішень, якими можливо буде керуватися під час забудови території міста.

Генплан міста є документом, що визначає планування і забудову, проте не враховує питання правового характеру, як-от формування обмеженого використання земель та кадастрової інформації для проведення АЗР.

Так, ПЗ-ГВ визначає:

- поділ земель на зони за використанням згідно з цільовим призначенням;

- вдосконалення структури територій через організаційні, правові, фрінансові та інші заходи з облаштування земель, покращення якісного стану, рекультивації, консервації тощо;

- необхідність економічного стимулювання щодо раціонального використання земель;

- надання необхідної інформації для обчислення розмірів земельного податку і орендної плати, а також пільг щодо оподаткування, встановлення попереднього розміру земельного податку;

- заходи із забезпечення правового режиму використання охоронних земель, захисних зон, відшкодування нанесених збитків власникам і користувачам у спосіб запровадження обмежень у використанні землі;

- визначення напрямів ресурсозберігаючої та природоохоронної діяльності;
- обгрунтування порядку тимчасового використання земель резервного фонду.

Отже, розробка ПЗ-ГВ повинна передувати генплану населеного пункту, оскільки він є законодавчо визначеним. Йог складовою може бути планування землекористувань, у процесі якого вирішуються питання:

- розробки проектів розподілу та укрупнення, а також впорядкування існуючих землеволодінь і користувань;

- визначення на місцевості меж адміністративно-територіальних утворень;

- обгрунтування умов встановлення меж територій з особливим режимом використання.

Модель взаємодії генплану міста та плану земельно-господарського впорядкування території в процесі використання землі приведені на рис. 2.

Отже, основним важелем створення законодавчо необхідних умов життєдіяльності, гарантії прав власності є технічна документація земельно-господарського впорядкування території.

Напрями удосконалення механізму соиіалъно-економічних відносин міста (C-EB) $i$ примісъкої зони.

Основною метою удосконалення механізму C-ЕВ міста і приміської зони є створення

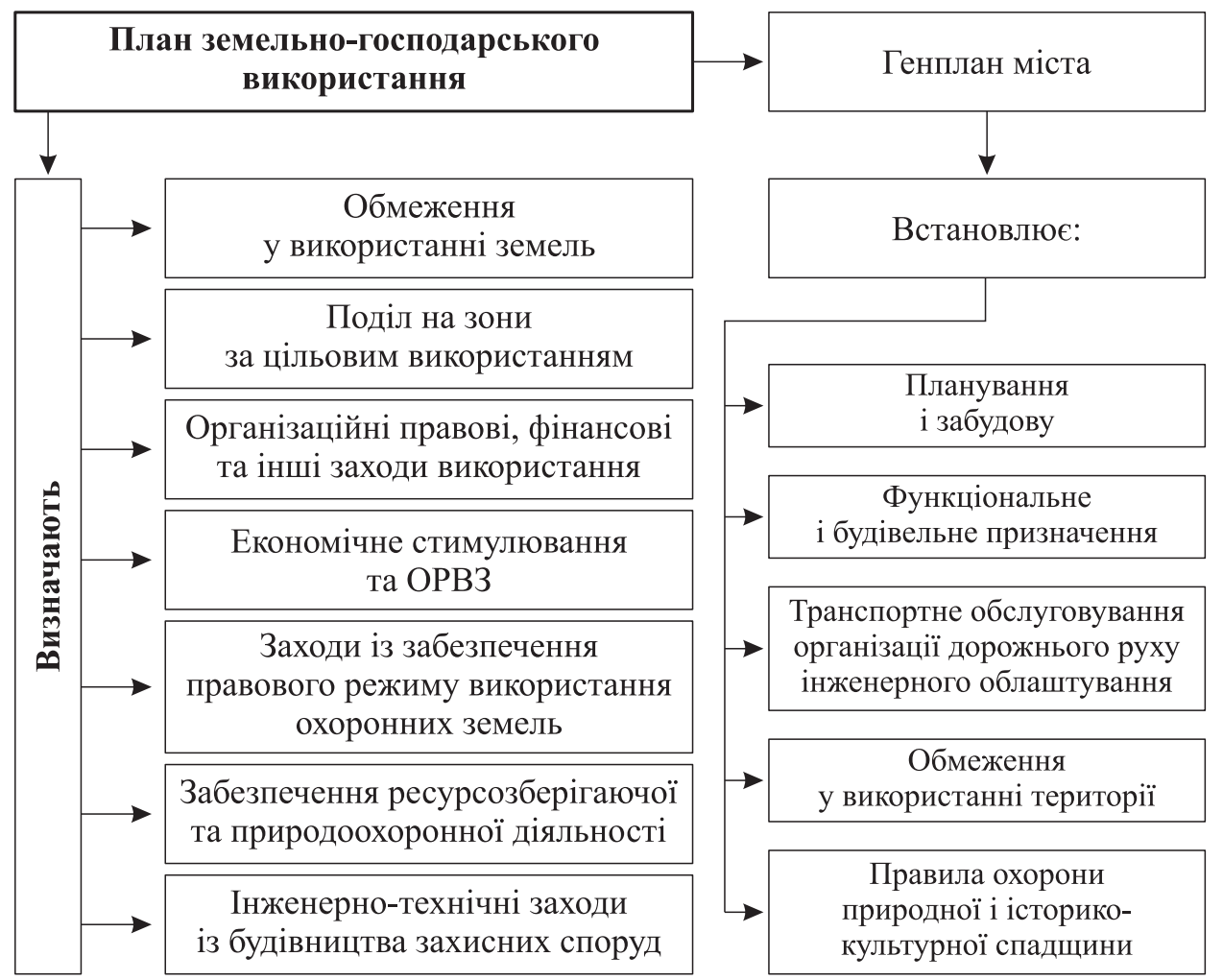

Рис. 2. Модель взаємодї генплану міста та плану земелъно-господарсъкого впорядкування території в процесі використання землі 


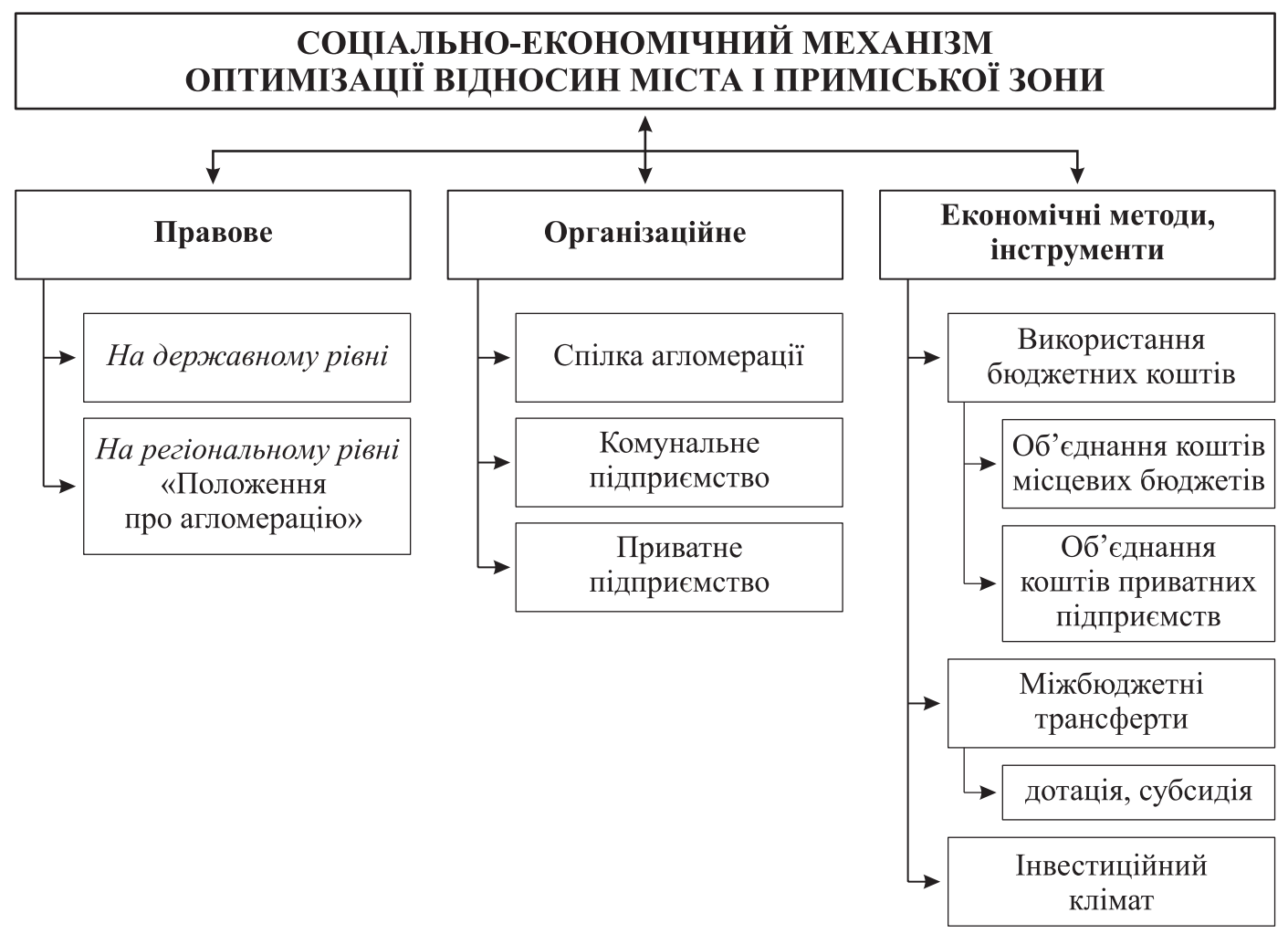

Рис. 3. Соціалъно-економічний механізм регулювання відносин міста і примісъкої зони

цілісного механізму, що вирішує питання задоволення індивідуальних і суспільних потреб з урахуванням збереження екологічного і ефективного використання території (простору).

Однією із складових розвитку С-ЕВ є економічний механізм регулювання відносин у місті та приміської зони.

Оскільки додаткову вартість в економіці створює синергетичний еоект (об'єднання можливостей і засобів), для ефективного розвитку СЕВ доцільно проводити об'єднання територіальних громад у велику потужну агломерацію.

Під агломерацією розуміють заселену територію, на якій проживає не менше 500 тис. мешканців і яка виділяється з-поміж інших територій високим соціально-економічним рівнем життя та господарювання громадян [12]. Для реалізації будь-якого завдання це сприятиме додатковим можливостям щодо забезпечення суспільних потреб, позитивно вплине на умови економічного розвитку агломерації.

Також ефрективним є створення Спілки агломерації, нової за організаційно-правовою і громадською характеристиками форми співпраці об'єднання у місті.

Така співпраця є ефрективною формою погодження інтересів, спільних дій агломерації, вона використовується для вирішення питань місцевого значення, забезпечення злагодженої взаємодії органів місцевого самоврядування 3 органами державної влади, для представлення інтересів територіальних громад.

Вказані заходи забезпечать всебічний розвиток міста як повноцінної земельно-господарської системи.

Висновки. Зважаючи на багатоаспектність використання земель міст, порівняно з іншими адміністративними одиницями, слід наголосити на специфічних особливостях впорядкування території та відносинах у системі адміністрування земельних ресурсів.

Особливої актуальності набувають питання організації використання земель в містах, обумовлених вирішенням двох питань земельної рефрорми, як-от рефрормування відносин власності та плата за землю. Однак на практиці, робиться зовсім мало щодо регулювання земельних відносин у напрямі головної мети земельної реформи - адміністрування земельних ресурсів.

Для забезпечення всіх аспектів використання земель міст нами запропоновано низку робіт, об'єднаних за принципом єдиної повноцінної системи. 


\section{СПИСОК ВИКОРИСТАНИХ ДЖЕРЕЛ}

1. Williamson Ian, Enemark Stig, Wallace Jude, Rajabifard Abbas. Land administration for sustainable development. Esri Press. 2010, 506 p. [Електронний ресурс]. Режим доступу: http//www.esri.com/ landing-pages/industries/land-administration/e-book\#sthash.KF25CaWH

2. Enemark S. Sustainable land governance: Spatially enabled, fit for purpose, and supporting the global agenda. [Електронний ресурс]. Режим доступу: http://www.landandpoverty.com/agenda/pdfs/paper/enemark_full_paper.pdf

3. Enemark S. Towards a Global Partnership for Capacity Building in Land Administration. [Електронний ресурс]. Режим доступу: http://siteresources. worldbank.org/INTIE/Resources/WBPaperEnemarkApril2011Final.pdf.

4. Dale P.F., McLaughin J.D. Land Administration. Oxford: Oxford University Press, 1999. 184 p.

5. Перович І.Л. Адміністрування земельних ресурсів в умовах невизначеності // Геодезія, картографія i аерофотознімання. 2014. Вип. 79. [Електронний ресурс]. Режим доступу: http://ena.lp.edu.ua

6. Третяк A.M. Екологія землекористування: теоретико-методологічні основи формування та адміністрування: монографія. Херсон: Грінь Д.С., 2012. 440 с.

7. Концептуальні засади формування системи адміністрування землекористування в Україні. [Електронний ресурс]. Режим доступу: http://ev.nmu.org.ua/docs/2016/3/ev20163_154-161

8. Питання та варіанти вдосконалення адміністрування земельних ресурсів в У країні. [Електронний ресурс]. Режим доступу: http://siteresources.worldbank.org/INTLGA/Resources/Ukraine_Synthesis_Report_Ukrainian

9. Земельний кодекс України. [Електронний ресурс]. Режим доступу: http:zakon.rada.gov.ua/laws/ show /2768-14

10. Рейтинг прозорості інвестиційного сектору 100 міст України. [Електронний ресурс]. Режим доступу: https://ti-ukraine.org/research/reitynh-prozorosti-investytsiinoho-sektoru-100-mist-ukrainy/

11. Про план земельно-господарського устрою. [Електронний ресурс]. Режим доступу: http://adhdportal. $\mathrm{com} / \mathrm{book}$

12. Основні вимоги до проекту «тимчасового» положення про львівську агломерацію. [Електронний ресурс]. Режим доступу: http: // vlp.com.ua/files

13. Тимченко С. Державний земельний кадастр слугуватиме основою цілісної системи геопросторових даних. [Електронний ресурс]. Режим доступу: http://www.kmu.gov.ua/kmu/control/ru/publish/ article

14. Factors and Risks in Land Resources Administration System. [Електронний ресурс]. Режим доступу: http://ijpsat.ijsht-journals.org

15. Інституціоналізація системи державного адміністрування землекористування. [Електронний ресурс]. Режим доступу: http://economyandsociety.in.ua/journal/5

\section{Інформація про автора}

Музика Наталія Миронівна - кандидат економічних наук, доцент кафедри кадастру територій, НУ «Львівська політехніка» (Україна, м. Львів; е-mail: Myzuka69@ukr.net)

Маланчук Марія Степанівна - кандидат технічних наук, доцент, заступник завідувача кафедри кадастру територій, НУ «Львівська політехніка»( Україна, м. Львів; e-mail: malanchuk. mari@gmail.com).

N.M. Muzyka

Ph.D.

National University «Lviv Polytechnic» (Ukraine, Lviv: e-mail: Myzuka69@ukr.net)

M.S. Malanchuk

Ph.D., Associate Professor

National University «Lviv Polytechnic»

(Ukraine, Lviv; e-mail: malanchuk.mari@gmail.com)

\section{FEATURES OF FUNCTIONING OF THE SYSTEM OF ADMINISTRATION OF LAND RESOURCES OF THE CITY}

In the Land Fund of Ukraine is the most diversified and complicated - land of cities, especially large ones, which act simultaneously as a place of permanent residence of the population and the placement of the bulk of capital investments. Questions of regulation of land relations, organization and management of the use of land in the city, as a holistic complex is engaged in administration. Important to create a mechanism for the administration of land resources (AZR), which should take over the management 
functions as a principle. With the development of the market more and more popularity is gaining the institution of property, in that thought and land. A permanent process of land reform requires the solution of issues related to administrative management of land. All questions related to agricultural lands, which will form the land of market and relations in this system, as well as which authorities have a managerial function, etc. The development of the national economy in the city determines the constant need for land as a spatial basis for objects, both residential and industrial. The search for such reserve areas in the cities is carried out with the purpose of removing the land for these needs and is extremely relevant as the land is spatially limited. Local authorities are responsible for the development of the city and the formation of land relations among them. To resolve these questions, the concept of development of land resources administration is proposed through the introduction and further resolution of the main strategic tasks (types of works) in cities.

Keywords: administration of land resources, land, city, investments.

\section{REFERENCES}

1. Williamson, I., Enemark, S., Wallace, J. and Rajabifard, A. (2010). Land administration for sustainable development. Esri Press, 506 p. [Electronic source]. URL: http://www.esri.com/landing-pages/industries/land-administration/e-book\#sthash.KF25CaWH

2. Enemark, S. Sustainable land governance: Spatially enabled, fit for purpose, and supporting the global agenda. [Electronic source]. URL: http://www.landandpoverty.com/agenda/pdfs/paper/enemark_full_paper.pdf

3. Enemark, S. Towards a Global Partnership for Capacity Building in Land Administration. [Electronic source]. URL: http://siteresources. worldbank.org/INTIE/Resources/WBPaperEnemarkApril2011Final. pdf

4. Dale, P.F. \& McLaughin, J.D. Land Administration. Oxford: Oxford University Press, 1999.184.

5. Perovych, I.L. (2014). Administruvannia zemelnykh resursiv v umovakh nevyznachenosti [Administration of land resources under uncertainty]. Heodeziia kartohrafiia $i$ aerofotoznimannia [Surveying, cartography and aerial photography], 79. [Electronic source]. URL: http://ena.lp.edu.ua (In Ukr.)

6. Tretiak A.M. (2012). Ekolohiia zemlekorystuvannia teoretyko-metodolohichni osnovy formuvannia ta administruvannia [Land use ecology: theoretical and methodological foundations of formation and administration]. Kherson: Hrin D.S. 440. (In Ukr.)

7. Kontseptualni zasady formuvannia systemy administruvannia zemlekorystuvannia v Ukraini [Conceptual bases of formation of the system of administration of land use in Ukraine]. [Electronic source]. URL: http://ev.nmu.org.ua/docs/2016/3/ev20163_154-161 (In Ukr.)

8. Pytannia ta varianty vdoskonalennia administruvannia zemelnykh resursiv v Ukraini [Issues and options for improving land administration in Ukraine]. [Electronic source]. URL: http://siteresources. worldbank.org/INTLGA/Resources/Ukraine_Synthesis_Report_Ukrainian (In Ukr.)

9. The Verkhovna Rada of Ukraine (2001), The Land Code of Ukraine, Retrieved from: http:zakon.rada. gov.ua/laws/show/2768-14 (date of accesse: 19.01.2019).

10. Reitynh prozorosti investytsiinoho sektoru 100 mist Ukrainy [Rating of transparency of the investment sector of 100 Ukrainian cities]. [Electronic source]. URL: https://ti-ukraine.org/research/reitynhprozorosti-investytsiinoho-sektoru-100-mist-ukrainy (In Ukr.)

11. Pro plan zemelno-hospodarskoho ustroiu [On the plan of land management]. [Electronic source]. URL: http://adhdportal.com/book (In Ukr.)

12. Osnovni vymohy do proektu «tymchasovoho» polozhennia pro lvivsku ahlomeratsiiu [Main requirements for the draft «provisional» provision for the Lviv agglomeration]. [Electronic source]. URL: http://vlp. com.ua/files (In Ukr.)

13. Tymchenko, S. Derzhavnyi zemelnyi kadastr sluhuvatyme osnovoiu tsilisnoi systemy heoprostorovykh danykh [State land cadastre will serve as the basis of a comprehensive system of geospatial data]. [Electronic source]. URL: http://www.kmu.gov.ua/kmu/control/ru/publish/article (In Ukr.)

14. Factors and Risks in Land Resources Administration System. [Electronic source]. URL: http://ijpsat. ijsht-journals.org.

15. Instytutsionalizatsiia systemy derzhavnoho administruvannia zemlekorystuvannia [Institutionalization of the system of state administration of land use]. [Electronic source]. URL: http://economyandsociety. in.ua/journa $1 / 5$ (In Ukr.)

\section{Authors}

Muzyka Natalia Myronovna - Ph.D., Assoc. Prof., Cand. sc. (econ.) National University Lviv Polytechnic (Ukraine, 79000, Lviv, 2 Karpinsky St.; e-mail: Myzuka69@ukr.net).

Malanchuk Mariia Stepanivna - Ph.D., Associate Professor, National University Lviv Polytechnic (Ukraine, 79000, Lviv, Karpinsky 2 St.; e-mail: malanchuk.mari@gmail.com). 